\title{
EM DIREÇÃO A UMA NOVA ÉTICA DO EXISTIR: FOUCAULT E A EXPERIÊNCIA DA ESCRITA
}

\author{
Jorge Ramos do $\dot{O}^{*}$ \\ Julio Groppa Aquino**
}

\begin{abstract}
RESUMO
No transcurso da trajetória intelectual de Michel Foucault, o tema da escrita parece não apenas não ter deixado de absorver seus interesses, como também provocou, em variadas circunstâncias, manifestações de sua parte, sobretudo em textos esparsos e entrevistas. Trata-se, assim, de uma questão que pode ser atestada de modo transversal, sucessivo e contínuo na obra foucaultiana, cuja abordagem analítica constitui o objetivo geral do presente artigo. Partindo da hipótese da escrita não apenas como um núcleo temático, mas também como um vetor éticoestético que transpassa a obra de Foucault, apresentamos dois patamares argumentativos complementares: num primeiro momento, focalizase a escrita foucaultiana no seio de um possível marco autobiográfico; em seguida, oferece-se uma perspectiva do trabalho escritural como experiência voltada à intensificação de um tipo de pensamento de natureza essencialmente crítica e, igualmente, à produção de uma superfície fática para modos inéditos de existir.
\end{abstract}

Palavras-chave: Foucault e a escrita. Experiência escritural. Escrita e crítica. Ética da existência.

\begin{abstract}
Throughout Michel Foucault's intellectual path, the matter of writing seems to have absorbed his interests and also have caused, in many circumstances, his own manifestations, mainly in scattered writings and interviews. It is therefore an issue that can be asserted in a transverse,

\footnotetext{
* Doutor em Ciências da Educação pela Universidade de Lisboa. Professor Associado do Instituto de Educação da Universidade de Lisboa-Portugal.E-mail: jorge.o@ie.ul.pt

** Doutor em Psicologia Escolar pelo Instituto de Psicologia da Universidade de São Paulo. Professor Associado da Faculdade de Educação da Universidade de São Paulo. E-mail: groppaq@usp.br
} 
successive and continuous manner on Foucault's work, whose analytical approach is the general goal of this paper. Setting forth from the proposition of writing not only as a thematic nucleus but also as an ethical-aesthetic vector running through Foucault's work, we present two complementary argumentative levels: one placing foucauldian writing within a likely autobiographical mark; the other suggesting a perspective of writing as an experience aiming at the enhancement of an essentially critical thought and, alike, at the production of a factual surface for unprecedented styles of being.

Keywords: Foucault and writing. Writing experience. Writing and critics. Ethics of being.

"Um pesadelo me persegue desde a infância: tenho, diante dos olhos, um texto que não posso ler, ou do qual apenas consigo decifrar uma ínfima parte. Eu finjo que o leio, sei que invento; de repente, o texto se embaralha totalmente e não posso ler mais nada, nem mesmo inventar, minha garganta se fecha e desperto. Não ignoro tudo o que pode haver de pessoal nessa obsessão pela linguagem que existe em todos os lugares e nos escapa em sua própria sobrevivência. Ela persiste desviando de nós seus olhares, o rosto inclinado na direção de uma escuridão da qual nada sabemos".

(Michel Foucault)

Ao iniciar o curso O governo de si e dos outros (2010d), nos primeiros dias de 1983, Michel Foucault trata de justificar seu percurso investigativo durante os anos em que estivera a ensinar no Collège de France. Já se passara mais de uma década desde que proferira sua aula inaugural, na qual se comprometera com um plano de atividades que findara por sofrer alterações acentuadas, sobretudo, aquela da guinada genealógica rumo aos gregos, em marcha desde $A$ hermenêutica do sujeito, que ali tomaria lugar novamente; uma guinada não antevista, talvez sequer intuída, nos tempos de $A$ ordem do discurso.

Não se tratava da primeira vez que o pensador se propunha a atribuir certa ordenação a uma trajetória intelectual marcada por deslocamentos indeléveis, cuja expressão máxima dar-se-ia, pouco mais tarde, no câmbio 
de crivo analítico entre o primeiro e os dois volumes subsequentes de História da sexualidade. Já em 1982, o pensador havia publicado em Critical Inquiry um texto crucial nessa direção: The subject and power (FOUCAULT, 1995a). Nele, apresentou uma síntese de sua empreitada teórico-metodológica das duas últimas décadas, apontando explicitamente o primeiro continente temático - o sujeito - como alvo precípuo de suas investigações, em detrimento do segundo, o qual se lhe costumava atribuir nos meios intelectuais de então como fulcro de suas investigações. Os processos de subjetivação dominantes na cultura ocidental se the apresentavam, então, como a plataforma privilegiada de problematização de um conjunto de problemas testemunhados no presente, particularmente aqueles relativos à questão da liberdade e seus constrangimentos múltiplos, a começar pelo próprio âmbito do pensamento no interior do qual se movia e com o qual se embatia sem cessar.

Em ambas as ocasiões, Foucault destacou o papel, a seu ver, fundante de um texto de 1784 de Kant - Was heisst Aufklärung? - que, a despeito de sua pontualidade, teria originado toda uma linhagem de pensamento devotada a uma ontologia do presente, impingindo à filosofia, a contrapelo de todo e qualquer ensejo metafísico ou universalizante, a tarefa de produzir uma análise inapelavelmente crítica da contemporaneidade; tarefa com a qual o pensador francês se identificava de imediato e em definitivo.

Nessa perspectiva, a questão fulcral perseguida por Foucault aqueles anos todos, sumarizada anteriormente em uma entrevista de 1975, se lhe afigurava da seguinte maneira: "Qual é esta linguagem que pode ser voltada contra nós, e que nós podemos voltar contra nós mesmos? Qual é este formidável entusiasmo da passagem à universalidade do discurso ocidental?" (FOUCAULT, 2006, p. 94).

Assim, na aula inaugural de 1983, Foucault destaca os três eixos temáticos que teriam constituído suas investidas em torno de uma história do pensamento, a fim de distingui-la de dois outros movimentos em voga: a história das mentalidades e a das representações. O que fazia a primeira diferir das demais era a análise dos focos de experiência disponíveis na cultura, consubstanciados na articulação de três eixos analíticos: 1) as formas de um saber possível; 2) as matrizes normativas de comportamento 
para os indivíduos; e 3) os modos de existência virtuais para sujeitos possíveis.

O projeto foucaultiano terá, então, um objetivo tão inequívoco quanto ambicioso: provocar torceduras de todo singulares no processamento de determinados problemas político-filosóficos recorrentes, bem como oferecer possibilidades de leitura dissonantes do diapasão interpretativo oferecido por seus contemporâneos. Segundo seus próprios termos, tratava-se de

substituir a história dos conhecimentos pela análise histórica das formas de veridicção, substituir a história das dominações pela análise histórica dos procedimentos de governamentalidade, substituir a teoria do sujeito ou a história da subjetividade pela análise histórica da pragmática de si e das formas que ela adquiriu, eis as diferentes vias de acesso pelas quais procurei precisar um pouco a possibilidade de uma história do que se poderia chamar de "experiências" (FOUCAULT, 2010d, p. 6-7).

A noção de experiência adquire, aqui, um relevo fático: tratar-se-ia daquilo que disporia determinados modos partilhados de ação e de resposta dos indivíduos ao que o tempo histórico lhes oferece. Mais especificamente, a experiência remeteria ao conjunto de sentidos que regulam as vivências capitais possíveis nas coordenadas do presente, em relação às quais todos e cada um estaríamos posicionados - incluídos aí os esquemas de condução da conduta, bem como os efeitos de resistência a tais esquemas.

Do ponto de vista estratégico, Foucault elege pari passu um tema-chave para cada um dos eixos três analíticos sobre os quais se debruça: a loucura, no primeiro caso; a criminalidade, no segundo; por fim, a sexualidade - todas elas tidas, por ele, como indiscutíveis focos de experiência do presente.

Se é bem verdade que o arco do pensamento foucaultiano privilegiou as três temáticas em voga, é verdade também que a questão da escrita parece ter atravessado de ponta a ponta seu percurso de ideias, por meio de um conjunto de reflexões que apontam para uma agonística em operação diuturna nas práticas abrigadas no gesto escritural - o que 
pode ser atestado desde as ponderações sobre a relação escrita/loucura (FOUCAULT, 1999, 2001a), passando ora pela função autor (FOUCAULT, 2001b), ora pela escrita/exame (FOUCAULT, 1987b, 2003a), até, por fim, a escrita de si (FOUCAULT, 2004a).

Soma-se a isso a própria escritura foucaultiana, erigida sob o signo não apenas de um estilo inconfundível, mas de uma afirmação ético-política inconteste. Isso porque Foucault opera de modo refratário a qualquer clamor de ascendência, de servidão cognitiva, de existência intelectual de segunda mão. Ansiava ele que seus livros operassem como artefatos explosivos - eficazes feito bombas e, igualmente, belos como fogos de artifício - que, depois de carbonizados pelo uso, deixassem nada além de um rastro marcante na memória (FOUCAULT, 2006). Tratavase, portanto, de um tipo de convocação do leitor que remetia a um jogo ininterrupto com a liberdade, o qual pressupunha não apenas o ensejo, mas o dever do desaparecimento daquele que escreve para que, desse modo, despontasse uma escrita sempre renovada; uma escrita sem fim.

Desta feita, a virtuosidade estilística do escritor e a expansividade contida em seus escritos constituem uma prova cabal da axiomática segundo a qual o trabalho da escrita confunde-se com o de viver ou, mais precisamente, com um modo intensivo de conduzir a própria existência. Escrever consistiria, assim, numa operação de alteração do que se pensa e, acima de tudo, do que se é; uma operação avessa, ademais, a qualquer apelo comunicativo ou normativo; em última instância, apenas superfície de irrupção de uma vida, somados aí seus revezes, suas circunvoluções e seu inacabamento compulsório.

Uma de suas declarações contida em uma entrevista parece não deixar margem de dúvida para o que aqui se conjectura:

[...] meus livros são, para mim, experiências, em um sentido que gostaria o mais pleno possível. Uma experiência é qualquer coisa de que se sai transformado. Se eu tivesse de escrever um livro para comunicar o que já penso, antes de começar a escrevê-lo, não teria jamais a coragem de empreendê-lo. [...] Sou um experimentador no sentido em que escrevo para mudar a mim mesmo e não mais pensar na mesma coisa de antes (FOUCAULT, 2010a, p. 289-290). 
$\mathrm{Na}$ breve passagem acima, Foucault evoca novamente a noção da escrita como um tipo de experiência que contemplaria não apenas os efeitos de sujeição, mas também os de transformação de si. Dito de outro modo, a escrita consistiria na arena onde se embateriam forças superlativas, tanto no sentido da investida unificadora dos modos de subjetivação aí implicados, quanto na direção de uma transfiguração radical desses mesmos modos, tendo em vista sua multiplicação, sua rarefação e, quiçá, seu desaparecimento em favor da irrupção de formas intensivas de apreensão e de ocupação do presente.

Partindo da hipótese geral da escrita não apenas como um núcleo temático, mas também como um vetor ético-estético que transpassa a obra de Foucault, o presente texto apresenta dois patamares argumentativos complementares: num primeiro momento, focaliza-se a escrita foucaultiana no seio de um possível marco autobiográfico; em seguida, oferece-se uma perspectiva do trabalho escritural como experiência voltada à intensificação de um tipo de pensamento de natureza essencialmente crítica e, igualmente, à produção de uma superfície fática para modos inéditos de existir.

\section{A experiência da escrita e a vontade de saber}

Nas variadas ocasiões em que Foucault foi questionado e teve oportunidade de se exprimir acerca da ligação que mantinha com a escrita, surpreendem as referências e imagens diretas à memória, à história pessoal e familiar. Sempre que o fez, exprimiu-se nuns termos tais que não apenas aproximavam invariavelmente a escrita a uma prática íntima e encarnada, mas que também a significavam como a superfície primeira de cristalização do tipo de análise crítica que se propunha a realizar como investigador. Escrever significava, assim, um modo de problematizar todas as dimensões de produção do discurso.

De súbito, as declarações de Michel Foucault acercavam-se de pesadelos e de formas singulares de prazer, conectando sempre o tempo antigo com o presente, numa obsessão expressa de articular e fusionar nele o próprio ser da linguagem. Uma das primeiras vezes que se debruçou sobre este tema familiar foi ao jornalista Claude Bonnefoy, do Le Monde, ainda em 1968. À pergunta sobre como teria inicialmente abordado a escrita, Fou- 
cault responde com a lembrança de uma passagem que o colocou, quando criança, no epicentro da violência típica da normalização escolar, cujos efeitos ter-se-iam estendido até os primeiros anos do ensino secundário, redundando em uma relação complicada e sobrecarregada com a escrita.

Uma de minhas lembranças mais constantes - certamente não a mais antiga, mas a mais obstinada - é a das dificuldades que tive para escrever bem. Escrever bem no sentido em que se entende o termo na escola primária, ou seja, criar páginas de escrita bem legíveis. Acredito - na verdade, tenho certeza - que, em minha classe e minha escola, eu era o mais ilegível (FOUCAULT, 2004d, p. 10).

Àquela recordação primeva juntar-se-ia outra: a de que o desejo de escrever só teria surgido nele relativamente tarde, quando, por volta dos 30 anos de idade, esteve fora da França. Se, por um lado, a estadia na Suécia, cuja língua admitia falar de modo sofrível, assim como o inglês, o teria impedido por muito tempo de se comunicar a contento, por outro, ela o teria feito compreender que poderia habitar a espessura de sua própria língua materna. Em outra ocasião, justificou:

Fui levado à Suécia, em 1955, pelo acaso, num momento em que eu tinha a firme intenção de passar o resto de minha vida entre duas valises viajando pelo mundo e, mais particularmente, de nunca pegar na pena. O pensamento de dedicar minha vida a escrever me parecia, então, completamente absurdo. Eu nunca havia pensado nisso de verdade. Foi na Suécia, durante a longa noite sueca, que peguei a mania e o mau hábito de escrever de cinco a seis horas por dia... Saí da França como uma espécie de turista inútil e supérfluo. Continuo me sentindo inútil, mas com a diferença de que não sou mais turista. Hoje, estou cravado no meu escritório (FOUCAULT, 2011b, p. 158).

A prática regular da escrita nasceria para Foucault, portanto, num lugar sem lugar, o qual lhe forneceu um tipo de experiência de constante deslocamento e de transformação, que não mais o abandonaria. A palavra escrita teria adquirido a partir dali certa valoração, transmutando-se para sempre num modo de existência. 
Desde o momento em que nele se dera essa espécie de conversão à escrita, Foucault viu-se preocupado, ato contínuo, com a materialidade das palavras. O problema que o acompanhava há muito era, efetivamente, o de tentar compreender, numa cultura como a nossa, o que implicava a existência das palavras, da escrita, do discurso.

Foucault reconhecia, assim, que sua investigação decorria de uma constatação corrente e banal, que também o inquietava desde muito cedo: "nunca atribuímos importância tão grande ao fato de que, ao final de tudo, o discurso existe" (FOUCAULT, 2004d, p.10). Mobilizava-se então para demonstrar que este seria certamente mais do que uma película transparente ou um espelho através do qual enxergamos as coisas em que pensamos. Persuadia-se de que, tal como sucedia no mundo da economia, também seria possível determinar a consistência e a densidade das leis do discurso. Porém, suas perguntas de investigador não iam no sentido de analisar a estrutura da linguagem, tal como então a faziam os linguistas: "trata-se de uma análise das coisas ditas, na medida em que são coisas”, explicava ainda ao mesmo jornalista do Le Monde. Assim, tudo em Foucault parecia concorrer para exprimir a evidência de que o discurso é ação, fabricando os seres e os objetos sobre os quais aparentemente apenas discorre ou que descreve. Na origem de seu trabalho de investigação residia, portanto, a premissa de que a linguagem constitui o mundo, não se limitando a mera função ideológica, de homologia ou de reflexo dele.

Uma e outra vez sustentou, ainda, que os seus livros eram fragmentos de autobiografia (FOUCAULT, 2010b, p. 358; 2010e, p. 372) e que suas passagens pelos hospitais psiquiátricos, prisões ou no terreno da sexualidade haviam sido decisivas na eleição das temáticas das investigações em que se embrenhava. Suas palavras podiam então assumir um tom confessional que jamais reapareceriam em qualquer outro domínio narrativo, posto que sempre se recusou a falar da sua existência privada. "Na minha vida pessoal", relatou numa entrevista a Roger PolDroit gravada em Junho de 1975, "eu me senti, desde o despertar da minha sexualidade, excluído, não verdadeiramente rejeitado, mas pertencendo à parte sombria da sociedade" (FOUCAULT, 2006, p. 71). Para ele, isso parecia converter-se rapidamente numa "espécie de ameaça psiquiátrica: se você não é como todo mundo, é porque é anormal, se você é anormal, 
é porque é doente" (FOUCAULT, 2006, p. 71). A partir de sua vivência íntima, Foucault compreenderia que "não ser como todo mundo, não ser normal e ser doente" constituíam categorias deveras distintas, mas que se achavam "assimiladas umas às outras" (FOUCAULT, 2006, p. 71).

O contexto de produção de História da loucura foi longamente abordado numa conversa com M. Osório em novembro de 1977 e que veio a público nos Quadernos para el dialogo (FOUCAULT, 2010f). É sabido que naquela investigação Foucault havia tratado não tanto da loucura ipso facto, mas da sua produção como doença mental, por intermédio do estatuto que passou a ser conferido aos loucos na Europa entre o século XVI e o começo do XX. Foucault informou que, após os seus estudos de filosofia, fora em 1955 trabalhar num hospital psiquiátrico com um estatuto particular, uma vez que "a profissão de psicólogo nos hospitais psiquiátricos não existia ou começava, apenas, a se desenhar, ao menos na França" (FOUCAULT, 2010f, p. 156), tendo permanecido dois anos numa espécie de estágio-limbo, sem uma tarefa específica, mas tolerado pelos profissionais de saúde, o que lhe teria permitido circular na fronteira entre dois mundos. E admitiu então: "as relações entre médicos e doentes, as formas de instituição, ao menos nos hospitais psiquiátricos, espantaram-me, surpreenderam-me, e levaram-me até mesmo à angústia" (FOUCAULT, 2010f, p. 156). Daí viria a deduzir o seu objetivo de estudo: não tanto saber o que se passaria na mente dos doentes, mas compreender uma dinâmica relacional tão tensa e dramática, empenhando-se em compreender o que se passava entre médicos e doentes "através dos muros, das regras, dos hábitos, dos constrangimentos, das coerções, das violências" (FOUCAULT, 2010f, p. 156).

Mesmo se o comum das práticas fosse organizado e justificado por um discurso que se apregoava científico, o que sobressaía e permanecia era "não mais do que um relacionamento muito estranho [...] de luta, de afrontamento, de agressividade" (FOUCAULT, 2010f, p. 156). Em uma palavra, Foucault almejava fazer a história da relação empírica entre a razão e a loucura, procurando contribuir para uma discussão mais geral em torno dos procedimentos pelos quais a sociedade moderna se empenhou em introduzir mecanismos de diferenciação entre os indivíduos. Terá sido, então, por razões biográficas que se atirou "de corpo inteiro na poeira 
dos arquivos", tentando encontrar "documentos, textos, testemunhos concernentes ao estatuto da loucura" na modernidade (FOUCAULT, 2010f, p. 159).

Desse registro referente ao trabalho do jovem Foucault restaria a evidência de que, para ele, suas formas de reflexão eram imediatamente "atadas, alimentadas, nutridas por experiências vividas" (2010f, p. 158). Entretanto, nada disso parecia ser novidade para ele. No prefácio que havia redigido para a edição inglesa de As palavras e as coisas, publicado em 1970, reconheceu também que uma série de coisas não lhe estavam claras e que, enquanto algumas pareciam muito evidentes, outras, ao contrário, resultavam-lhe muito obscuras (2000b, p. 182). Diria depois, sobre $A$ arqueologia do saber, que havia aí buscado analisar um sistema de pensamento que lhe era pessoal, e que o livro apenas espelhava a maneira como, por intermédio de conexões as mais diversas, ele o havia conseguido escrever (2003e). Apresentava, assim, aos leitores um traçado escritural marcado por deslizamentos, roturas e fendas, como se pudesse fazer reverberar, desse modo, a movência geral que sentia atingir o mundo.

Nos livros que escrevo, tento cernir um tipo de problema que ainda não tinha sido enfocado. Conseqüentemente, nessas condições, é necessário que eu consiga fazer aparecer no final do livro um certo tipo de problema que não pode ser transcrito no título. Estas são as duas razões pelas quais existe, entre o título e o livro, essa espécie de "jogo". É certo que seria preciso me dizer que esses livros não rimam de forma alguma com esses títulos e é preciso efetivamente mudálos, ou que há uma espécie de desfasagem que surge entre o título do livro e seu conteúdo; e que essa desfasagem é para ser tomada como a distância que tomei de mim mesmo ao fazer esse livro (FOUCAULT, 2004f, p. 260).

O tema do distanciamento de si próprio parecia residir, em Foucault, na oportunidade única e imperativa proporcionada pela prática da escrita. Em abril de 1979 publicou em Le nouvel observateur uma pequena recensão crítica, a que deu o expressivo título de Para uma moral do desconforto; nela exprimiu uma das suas máximas éticas: "minha maneira de não ser mais o mesmo é, por definição, a parte mais singular do que sou" 
(FOUCAULT, 2010g, p. 280). A análise que fazia da sua trajetória era, portanto, a de alguém cuja exigência de identidade e injunção de romper confluíam para sentir o peso do mundo também na relação consigo mesmo.

Outra declaração do pensador é elucidativa do gesto escultural desmedido vetorizado pelos trabalhos da escrita, segundo o qual o que se visa é a dispersão, a rarefação e, então, a elisão subjetivas. Isso porque, no duelo contra o hábito autoral, são as forças de um vir a ser outro, e não só da impessoalidade, que aí emergem.

A escrita se desenrola como um jogo que vai infalivelmente além de suas regras, e passa assim para fora. $\mathrm{Na}$ escrita, não se trata de manifestação ou da exaltação do gesto de escrever; não se trata da amarração de um sujeito em uma linguagem; trata-se da abertura de um espaço onde o sujeito que escreve não pára de desaparecer (FOUCAULT, 2001b, p. 268).

O ensejo de distanciamento do estatuto jurídico da figura de autor levou Foucault a admitir que sonhava com uma nova era da curiosidade, uma nova maneira de imaginar e de efetivar o trabalho científico, a qual fizesse calar o desejo de monarquia ou de tutela intelectual que tão frequentemente o assediava. Para Foucault, a palavra curiosidade deveria, ao contrário, ser apropriada como inquietação, remetendo à responsabilidade que se assume por tudo que existe e que pode vir a existir. Era necessário, em sua opinião, que se criassem redes e que se buscassem formas de desmultiplicar o conhecimento, para que então pudessem surgir diferenciações úteis no plano da construção e da circulação do saber. Entrevia, igualmente, a possibilidade de toda uma postura ética que tivesse uma consciência aguda do real - em lugar de se imobilizar nele - que ora estranhasse, ora singularizasse tudo o que se movia ao seu redor. Em seus termos, era mister "uma certa obstinação em nos desfazermos de nossas familiaridades e de olhar de maneira diferente as mesmas coisas; uma paixão de apreender o que se passa; uma desenvoltura, em relação às hierarquias tradicionais, entre o importante e o essencial" (FOUCAULT, 2000a, p. 304). Curiosidade, em suma, como o motor que fizesse fazer agir as diferenças, em oposição frontal à ideia corrente da universidade como zona reservada e parque cultural dos especialistas ameaçados pela vulgarização cultural. 
Tratava-se, ademais, de conferir um novo entendimento à filosofia. $\mathrm{Na}$ esteira do opúsculo kantiano de 1784 que encantava Foucault, esta disciplina passaria a ser vista como o movimento ou a atividade crítica por meio da qual, "não sem esforços, hesitações, sonhos e ilusões, nos separamos daquilo que é adquirido como verdadeiro, e buscamos outras regras de jogo" (FOUCAULT, 2000a, p. 305). Havia, assim, que modificar por completo a missão da formação recebida na universidade, sendo que esta passaria a ser pensada de tal modo que permitisse ao indivíduo modificar-se à sua maneira, o que somente aconteceria se o ensino se convertesse numa prática permanentemente aberta.

Sua hipótese remetia aqui, decerto, à democratização radical não apenas do acesso ao conhecimento científico, mas a todos os meios e processos que permitem a produção e recriação infinita do saber: "digo que a distribuição das pessoas em uma cultura deve ser incessante e tão polimorfa quanto possível" (FOUCAULT, 2000a, p. 305). Daí a hierarquia universitária também ser abertamente questionada por Foucault (2000a, p. 305): "não deveria haver, por um lado, essa formação à qual nos submetemos e, por outro, essa informação à qual se é submisso". Para tanto, vislumbrava um papel ativo da investigação, fosse ela de natureza teórica ou empírica, nas "mudanças no comportamento, na conduta real das pessoas, em sua maneira de ser, em sua relação consigo mesmas e com os outros" (FOUCAULT, 2000a, p. 306).

Em outra entrevista a La Quinzaine littéraire, publicada em março de 1968, Foucault refletiu, ainda sob o efeito da publicação de $A s$ palavras e as coisas, sobre as instâncias de difusão do saber no contexto do desenvolvimento das ciências humanas na modernidade, a fim de operar a crítica à exiguidade do espaço social em que o conhecimento transitava ou à sua proteção no interior de instituições educativas, mormente as acadêmicas, a que só um número restrito de indivíduos tinha acesso. Negou mais uma vez a parábola de um mundo dividido entre espíritos sábios e ignorantes, afirmando que o saber não constituía uma potência divisível ou hierarquizável. Ao contrário, reivindicava para si uma herança de sentido inverso e que concebia o saber como estrutura caída no domínio público, imaginando sempre uma ligação da pesquisa especializada ao coletivo. 
Nos dias de hoje, estamos num grau muito desenvolvido de uma mutação começada nos séculos XVII e XVIII, quando finalmente o saber se tornou uma espécie de coisa pública. Saber era ver evidentemente o que todo indivíduo situado nas mesmas condições poderia ver e constatar. Nesse sentido, a estrutura do saber se tornou pública. Todo mundo tem o saber. Apenas, ele não é sempre o mesmo, não está sempre nem no mesmo grau de formação, nem no mesmo grau de precisão etc. Todavia, não há os ignorantes de um lado e os eruditos do outro. $\mathrm{O}$ que se passa num ponto do saber agora é sempre muito rapidamente repercutido num outro ponto de saber. E, nessa medida, acredito que o saber nunca foi mais especializado e, no entanto, nunca se comunicou de modo mais rápido com ele mesmo (FOUCAULT, 2011c, p. 175).

O que usualmente entendemos por criatividade parecia sustentar em Foucault toda uma arte de viver. A compreensão de que os procedimentos de inteligibilidade e racionalidade portavam uma vocação transformadora faria certamente com que suas análises, em lugar de fazerem retrair, deslocassem sem parar os seus focos. Por isso, Foucault afirmava que escrevia os seus livros como que em rede, visto que eles se cruzavam incessantemente entre si: o primeiro deixava abertos problemas nos quais o segundo se apoiava, solicitando um terceiro, mas sem que houvesse, entre eles, uma continuidade linear.

O pensador francês gostava de enfatizar que, quando começava a redação de um livro, não entrevia claramente qual metodologia empregaria, admitindo portanto que forjava um tipo específico - nunca igual, portanto - de procedimento em cada um de seus diferentes projetos. Findo o trabalho, confessaria noutra entrevista dada em 1978, "posso, por uma espécie de olhar retrospectivo, extrair da experiência que acabo de fazer uma reflexão metodológica que tira o método que o livro pôde seguir" (FOUCAULT, 2010a, p. 290). Foi essa dinâmica que o levou a escrever em alternância livros que denominava de exploração, como História da loucura e Nascimento da clínica, e também livros de método, como $A$ arqueologia do saber, todos surgidos antes de Vigiar e punir e História da sexualidade I. 
Do olhar retrospectivo sobre seu trabalho, Foucault parece subtrair a clareza máxima da vertigem paradoxal em que o ofício da escrita o envolvia. Reconhecia-se inteiramente instalado numa arte - que dizia inteiramente prazerosa e doce para si - de desnudar, um após outro, os episódios singulares e bizarros da grande fábula do mundo. Tratava-se, para ele, de ir ao mais fundo da história e nele se manter por toda uma vida, tecendo as modalidades genealógicas do arbitrário, do sem fundamento e da morte de todas as verdades do homem. Tratava-se também de ousar permanecer nessa cética inventividade, mesmo sabendo que ela jamais anularia o vazio de conhecimento que a linguagem sempre instaura no espírito de quem se sente unicamente interpelado por ela.

Sinto uma impressão de veludo quando escrevo. Para mim, a idéia de uma escrita aveludada é como um tema familiar, no limite do afetivo e do perceptivo, que não pára de assombrar o meu projeto de escrever, não pára de guiar a minha escrita quando estou escrevendo, que me permite a cada momento escolher as expressões que quero utilizar. A doçura é uma espécie de impressão normativa para a minha escrita. Assim fico muito espantado ao constatar que as pessoas tendem a enxergar em mim alguém cuja escrita é seca e mordaz. Refletindo sobre isso, acho que são elas que têm razão. Imagino que deve existir, em minha caneta, uma velha herança do bisturi. Talvez, afinal, eu trace sobre a brancura do papel os mesmos sinais agressivos que meu pai traçava sobre os corpos dos outros que ele operava. Transformei o bisturi em caneta. Passei da eficácia da cura à ineficácia da livre proposta, substituí a cicatriz sobre o corpo pela grafitagem sobre o papel, substituí o inapagável da cicatriz pelo sinal perfeitamente apagável e rasurável da escrita. Talvez seja mesmo o caso de ir mais longe ainda. A folha de papel, para mim, talvez seja como os corpos dos outros (FOUCAULT, 2004d, p. 10).

Embora Foucault afirmasse que a prática da escrita não constituía nenhuma necessidade peremptória, havia de admitir noutra entrevista que, por intermédio dela, se introduzia numa espécie de túnel interminável. Com efeito, afirmou que seus livros resultavam bem mais longos do que o inicialmente previsto, já que sentia a maior dificuldade de conseguir parar quando começava a redação de um texto. Sem embargo, também 
confidenciou que tinha um enorme desejo em encontrar uma via alternativa a essa atividade de colocar palavras no papel, que considerava demasiado "fechada, solene e redobrada sobre si mesma" (FOUCAULT, 2006, p. 81). $\mathrm{E}$ foi então que mencionou uma outra fantasia recorrente. Idealizava um futuro em que se via totalmente absorvido por um tipo de tarefa na qual o tempo da execução e da circulação do texto surgissem automaticamente ligados: "Eu gostaria que ela [a escrita] fosse um algo que passa, que é jogado assim, que se escreve num canto de mesa, que se dá, que circula, que poderia ter sido um panfleto, um cartaz, um fragmento de filme, um discurso público, qualquer coisa..." (FOUCAULT, 2006, p. 81).

Cumpre-nos reconhecer, aqui, que tal hipótese não remetia a uma economia minimalista da narrativa, como a do haicai; consistia, antes, num tipo de atividade que classificaria de "escrita descontínua e que não se percebesse como sendo uma escrita" (FOUCAULT, 2006, p. 82). Tratarse-ia de uma modalidade de expressão que se funcionasse valendo-se, de forma indistinta e até simultânea, do papel em branco, a máquina, a caneta, o teclado, o pincel ou a câmara. Em resumo, o essencial estaria em se ter sempre ao alcance da mão um instrumento de linguagem que permitisse abordar de forma inusitada a variabilidade de situações-problema que se lhe apresentassem.

Por certo que esse horizonte onírico não se concretizaria. Mas, é igualmente verdadeiro que sua obra, se compreendida em sua integralidade, evidencia, na variabilidade das modalidades de abordagem do passado e do presente, uma liberdade radical em relação à ambição totalizante e totalizadora da racionalidade descritiva de seus contemporâneos. Foucault persuadiu-se de que uma antropologia empírica como a sua, organizada para captar e acumular sem parar as singularidades e as rupturas do tempo, tinha por missão evidenciar a fragilidade congênita de todos os modelos explicativos que sustentam os discursos e as intervenções operadas em nome da defesa de um tipo de particular de existência. Ora, é em favor de uma crítica a toda e qualquer mundividência onipotente que sua escrita se liga, interna e substantivamente, a uma miríade de intervenções subsequentes, permitindo supor que a fantasia foucaultiana de uma máquina multidiscursiva prossegue na contemporaneidade o caminho da diferenciação e da dissintonia, sempre circunscritas a um approach específico, claro está (FOUCAULT, 2003g). 
O trabalho seminal sobre a loucura já parecia decorrer da constatação de visu do jovem Foucault segundo a qual não temos nenhuma forma de acesso às coisas em si. As paisagens escriturais que viria a construir depois, armando-as de toda uma parafernália conceitual, tinham por objetivo demonstrar, de modo exuberante, que, sendo o homem uma invenção do saber construído na viragem do século XVIII para XIX, a identidade é inexoravelmente plural e, por isso, incapturável. Assim, os escritos foucaultianos arrogam uma origem contextual e uma contingência histórica de toda ação sobre a existência. Como seu modo de operar analiticamente contrasta com a tese da origem transcendental do humano que sempre acompanha os vários poderes do tempo - venham de onde vierem, apresentem-se como se apresentarem -, eles contrastam sobremaneira com o monolitismo das intervenções ético-políticas exercidas pelas instituições responsáveis não apenas por produzir, mas por manter em pleno funcionamento a maquinaria da governamentalidade.

Ora, seria possível, então, imaginarmos um pensamento vitalista desenvolver-se no interior de uma análise que se organiza a partir de visões tormentosas e de violências sem nome conduzidas exatamente em nome da manutenção de um tipo exclusivo de vida? A escrita de Michel Foucault parece, salvo melhor juízo, responder abertamente que sim, que podemos imaginar formas sempre novas de existência, para além dos esquemas de racionalização disponibilizados hic et nuc como prioridade ontológica. A rasura do estereótipo a que conduz a compreensão do arbitrário de qualquer crivo de conduta permitiria, outrossim, fazer nosso pensamento deslizar suavemente para a ideação de modos ambivalentes e heterodoxos tanto de habitarmos o presente, como de nos abrirmos para o devir dos acontecimentos que ele comporta.

\section{A escrita como arte de existir}

Não considero necessário saber exatamente quem sou. O que constitui o interesse principal da vida e do trabalho é que eles lhe permitem tornar-se diferente do que você era no início. Se, ao começar a escrever um livro, você soubesse o que irá dizer no final, acredita que teria coragem de escrevê-lo? O que vale para a escrita e a relação amorosa 
vale também para a vida. Só vale a pena na medida em que se ignora como terminará (FOUCAULT, 2004h, p. 294).

As declarações acima, contidas em uma entrevista realizada na Universidade de Vermont em outubro de 1982, delimitam um tipo específico de relação de Foucault com a escrita e com o uso público que dela desejou que se fizesse. Amiúde defendeu que o ofício de professor/ pesquisador correspondia a uma prática perpétua de desdobramento de si mesmo e que os resultados aí atingidos, expressos na forma de livros ou artigos, deveriam ser tomados como experimentos descritivos destinados a problematizar as evidências incontestadas do presente, sem jamais virem a se constituir em prédicas sobre ou para os indivíduos no tempo.

A prática da escrita, tal como a vinha concebendo, correspondia a uma convocação para o combate mais violento de todos: impor-se um permanente espírito de vigília e ir de encontro, por inteiro, à lei moral, a fim de encontrar meios de estiolá-la. Como se ele nos estivesse sempre a querer mostrar que o traçado que a verdade expressa será sempre do domínio do fortuito e nunca o de caminho que possamos tomar como único ou mais correto.

Mesmo que a argumentação expendida não reiterasse senão o permanente ir e vir entre a vida quotidiana, o trabalho teórico e a investigação histórica, numa produção escrita toda ela marcada pelo deslocamento ou até pelo acaso, é também fato inegável que o posicionamento crítico de Foucault se manteve inalterado ao longo da vida, o que torna os seus trabalhos tão próximos e familiares na distância, por vezes acentuada, que eles estabelecem entre si. A potência aberta que o conjunto da sua obra consubstancia parece ter tido, desde sua origem, apenas um desígnio: o de tomar o mundo tal como ele se apresenta não como uma realidade dada, que porventura fosse passível de ser conveniente e amplamente descrita ou manipulada, mas como fonte inesgotável de problemas cuja constituição histórica remetia o investigador ao palco incomensurável das relações de força e de dominação em circulação na cultura.

Assim, o projeto foucaultiano, como ele próprio também o reconhecia desde os anos 1970, foi sempre o de interrogar tudo aquilo que se apresenta como verdade atemporal; um projeto que se desdobrou com 
o fito de produzir precisamente uma história do presente, tendo em mente, de antemão, que qualquer investigação assim empreendida supunha uma resposta precária e contingente, e que esta, longe de bastar-se a si própria, rapidamente se ramificaria numa infinidade de novas interrogações.

Seus esforços conduziam-no, assim, a um ceticismo radical, o qual tinha por princípio a recusa do ponto em que nos encontramos como sendo a "conclusão de um progresso que se teria de reconstituir na história, quer dizer, ter a respeito de nós mesmos, de nosso presente, do que somos, do aqui e do hoje, esse ceticismo que impede que se suponha que é melhor, ou que é mais" (FOUCAULT, 2003c, p. 170). Não era nunca, com efeito, o apaziguamento derradeiro que procurava, mas apenas uma nova chance para que se reabrisse o movimento de análise. Eis, a nosso ver, como um projeto de investigação voltado ao incitamento ao pensar desassombrado converter-se-ia numa escrita polimorfa.

Por essa razão, seus escritos, mesmo tendo uma superfície única de emergência, não indicam uma unidade nem teórica, nem metodológica, mas tão somente a busca crítica da palavra e da análise plural. Uma de suas declarações dá conta claramente desse seu intento:

É verdade que tratei, prioritariamente, fenômenos do passado: o sistema de exclusão e a prisão dos loucos na civilização europeia do século XVI ao século XIX, a constituição da ciência e da prática médicas no início do século XIX, a organização das ciências humanas nos séculos XVIII e XIX. Mas, se me interessei-de fato, me interessei profundamente - por esses fenômenos foi porque vi neles maneiras de pensar e de se comportar, que são ainda as nossas. Tento pôr em evidência, fundamentando-me em sua constituição e sua formação histórica, sistemas que ainda são os nossos nos dias de hoje, e no interior dos quais nos encontramos apanhados. Trata-se, no fundo, de apresentar uma crítica de nosso tempo, fundamentada em análises retrospectivas (FOUCAULT, 2003b, p. 13).

Se Foucault teve um cuidado extremo em rodear seu modus faciendi de esclarecimentos, é natural que nele se sucedessem igualmente as explicações relativas ao destino e uso que gostaria fosse feito dos seus textos. Este remetia ao desejo de irradiação social e de desmultiplicação da 
prática da escrita, numa recusa cabal à lógica tão enraizada de sacralização da função autor e de associação do texto científico com a estabilização ordenada da verdade; lógica fundamental, aliás, para a edificação do Estado moderno. Para quem não se cansou de afirmar que sempre se atinha aos fenômenos que se passava nele e por ele, era quase automática a necessidade de sublinhar que suas narrativas, embora de vocação crítica e envolvidas com situações as mais das vezes identificáveis na atualidade, apenas transportavam formas de questionamento, sem jamais proporem-se a fazer lei, oferecer ensinamentos ou precauções em relação a determinada prática ou forma de organização da vida humana.

Com frequência, repetia que, para ele, o ato de pensar não era mais que a elaboração de um trabalho crítico que incidia sobre o próprio pensamento. Ora, essa asserção trazia no bojo o desígnio de questionar incisivamente o território social em que o seu próprio discurso se desencadeava. O jogo de produção da diferença impunha-lhe uma permanente vigilância ante o locus de dimanação, circulação e validação da própria linguagem científica. Havia, pois, que refletir criticamente sobre a multiplicidade de regras e mecanismos institucionais que se abatiam sobre ele. Cumpre, assim, verificar que a consciência acerca desse outro procedimento foi bem matinal em Foucault. Tome-se esta declaração proferida ainda no verão de 1968 num debate no Círculo de Epistemologia e inserida nos Cahiers pour l'analyse:

Analiso o espaço em que falo. Exponho-me a desfazer e a recompor esse lugar que me indica as balizas primeiras do meu discurso; tento dissociar dele as coordenadas visíveis e sacudir sua imobilidade de superfície: arrisco suscitar a cada instante, sob cada uma de minhas proposições, a questão de saber de onde ele pode nascer: pois tudo isso que digo poderia ter como eleito deslocar o lugar de onde eu o digo. Embora aí esteja a questão: de onde você pretende falar, você que quer descrever - de tão alto e de tão longe - os discursos dos outros? Responderei somente: eu acreditei que falava do mesmo lugar que esses discursos e que, definindo seu espaço, eu situaria minha intenção; mas devo agora reconhecê-lo: de onde mostrei que eles falavam sem dizê-lo, eu mesmo só posso falar a partir dessa diferença, dessa ínfima descontinuidade deixada, já detrás dele, por meu discurso (FOUCAULT, 2000c, p. 96-97). 
O trabalho da escrita para Foucault parece, assim, tomado de uma dupla radicalidade: supunha uma entrega sem condição ao seu exercício e, ao mesmo tempo, um combate corpo a corpo com todo e qualquer sinal que a pudesse sacralizar no espaço público. A escrita originaliza-se como o horizonte por meio do qual emanaria a possibilidade de novas formas de existência e de debate público no mundo social do segundo pós-guerra, que Foucault sentia como estando cada vez mais pressionado pelos discursos multiplicados dos pregadores da verdade objetiva e salvadora, redundando numa espécie de fascismo brando identificável nos discursos em voga (FOUCAULT, 2010c).

O projeto foucaultiano é, outrossim, todo ele atravessado pela consciência de que o saber se constrói unicamente no deslocamento, na transformação e na ultrapassagem dos problemas já refletidos e ensaiados por outrem. Essa espécie de ofício incansável e infinito da palavra escrita supunha que ele começasse por negar com veemência a designação de teórico. Seu caso não era o de alguém que intentava construir um sistema explicativo global, aplicável de maneira homóloga a diferentes campos ou problemas, mas, em vez disso, o de um investigador que se descobria inteiramente mobilizado por um processo de intensificação existencial que, após a finalização de seus livros, tão somente o levava a ser outro, isto é, a não pensar a mesma coisa que antes pensava.

Sua atividade reflexiva não se esgotava, contudo, nos livros. Especialmente na década de 1970, continuou a produzir, simultaneamente aos cursos que oferecia junto ao Collège de France, uma série de outros escritos e de intervenções públicas, os quais entrevia e justificava como propulsores de novos projetos adiante. Sua participação junto ao Groupe d'information sur les prisons e a criação de Vigiar e punir talvez sejam os melhores exemplos disso. Mas o importante, nesse caso, é reconhecermos que não se tratava de estabelecer um conjunto de procedimentos geral e válido em quaisquer circunstâncias. Longe disso. Declarou a propósito, numa entrevista: "o que escrevi não é jamais prescritivo nem para mim nem para os outros; é, quando muito, instrumental e sonhador" (FOUCAULT, 2010a, p. 290).

A prática da escrita, defendia ainda Foucault, traduzia uma dinâmica de articulação social que lhe importava assinalar. Se podia reconhecer que 
se tratava nela de mais uma experiência que fazemos inteiramente sós, era também fato que escrever escapava à pura subjetividade, na medida em que amiúde sucedia que os leitores não retomassem o texto nos mesmos termos do autor, antes o cruzando, atravessando e ultrapassando com o propósito de construir a sua própria visão da realidade.

$\mathrm{Na}$ mesma entrevista, Foucault fez o balanço do que sucedera com Vigiar e punir, publicado cinco anos antes. Compreendia que, sendo embora um livro de pura história, as reações a ele eram sempre intensas, não obstante contrastadas. E isso teria sucedido porque, em seu entendimento, as pessoas "tinham a impressão de que se tratava de questões delas próprias, ou do mundo absolutamente contemporâneo, ou de suas relações com o mundo contemporâneo, nas formas em que este é aceito por todos" (FOUCAULT, 2010a, p. 295). Foucault podia então supor que sua escrita possibilitava a emergência do que os leitores podiam reconhecer como sendo suas próprias ligações à modernidade. Como se Vigiar e punir, focalizado nas práticas disciplinares e de enclausuramento dos corpos e das almas num período longínquo, não explicitasse senão a complexa territorialização da atualidade em torno da afetação da conduta individual pelas relações de poder-saber. Ora, o próprio Foucault (2010a, p. 295) admitiria a respeito que seu empreendimento historiográfico havia sido produzido à medida que ele fora participando, "durante alguns anos, de grupos de trabalho, de reflexão sobre e de luta contra as instituições penais". Todo um trabalho complexo e difícil de problematização, produzido inteiramente no presente - levado por ele a cabo nas prisões de França dos anos 1970 - estaria assim na base de uma investigação essencialmente histórica. Por essa razão, quando o livro foi publicado, as reações foram imediatas, oscilando entre o reconhecimento, de um lado, de que o livro oferecia observações pertinentes e, de outro, de que tais observações eram também susceptíveis de bloquear a atividade dos técnicos. Ora, justamente essa vocação crítica e não prescritiva deixou em Foucault a viva impressão de que Vigiar e punir fora um trabalho bem sucedido. "Ele é lido", reconhecia com entusiasmo, "como uma experiência que muda, que impede que se seja sempre o mesmo, ou de ter-se com as coisas, com os outros o mesmo tipo de relação que se tinha antes da leitura" (FOUCAULT, 2010a, p. 296). Era-lhe então lícito supor que Vigiar e punir nada mais fizera "do 
que se inscrever em alguma coisa que estava, efetivamente, em curso" no processo de "transformação do homem contemporâneo em relação à ideia que tem de si mesmo" (FOUCAULT, 2010a, p. 296). Reconheceu também que o livro operara nesse sentido como apenas mais um agente. $\mathrm{E}$ arrematou: "eis o que é, para mim, um livro-experiência, em oposição a um livro-verdade e a um livro-demonstração" (FOUCAULT, 2010a, p. 296).

Foucault repetiu amiúde que havia de ter coragem, ousadia intelectual e convicção na própria escrita, mas ser radicalmente modesto acerca do impacto, da influência e do uso que ela pudesse ter sobre e por terceiros. O que parecia preocupá-lo era, no mais das vezes, a forma como seus livros pudessem provocar uma interferência no processo histórico de constituição das formas de veridicção circulantes. No caso de História da loucura, era-lhe claro que havia obtido um efeito real "sobre a maneira como as pessoas percebem a loucura" (FOUCAULT, 2003d, p. 321). Por isso, dizia-se animado de uma esperança: a de que os trabalhos que produzia tomassem "a sua verdade uma vez escritos, e não antes" (FOUCAULT, 2003d, p. 321), que sua materialidade estava apenas em as pessoas poderem se servir deles para empreenderem formas particulares de luta. Entendia que não fazia uma obra no sentido clássico do termo, mas que procurava escrever coisas que pudessem ser utilizadas por pessoas diferentes e nos mais variados lugares. Para ser mais claro acerca do uso social que imaginava para os seus textos, recorreu, em uma conversa com estudantes americanos ainda no decurso dos anos 70, a uma analogia certeira:

Eu imaginaria [...] meus livros como bilhas que rolam. Elas são captadas, tomadas, lançadas novamente. E se isso funciona, tanto melhor. Mas não me pergunte quem eu sou antes de utilizar minhas bilhas para saber se elas não vão estar envenenadas, ou se elas não são bem esféricas, ou se elas não rolam no sentido certo. Em todo caso, não é pelo fato de ter me perguntado a minha identidade, que você saberá se o que faço é utilizável (FOUCAULT, 2006, p. 80).

Nessa perspectiva, o papel do intelectual, consubstanciado em efeitos como aqueles testemunhados com História da loucura e depois com Vigiar e punir, seria precisamente o de "lutar contra as formas de poder ali 
onde ele é, ao mesmo tempo, o objeto e o instrumento disso: na ordem do 'saber', da 'verdade', da 'consciência', do 'discurso'” (FOUCAULT, 2003f, p. 39). Propunha-se ele, então, a abdicar por completo da posição de juiz ou de testemunha universal, acrescentando que fazia as análises que fazia não porque gostasse de arbitrar polêmicas, mas porque estivera ligado a certos enfrentamentos com a medicina, a psiquiatria, a penalidade etc. Queria-se, desse modo, bem afastado de uma tradição secular de pretensão à totalidade e à objetividade, não entrando no debate corrente em torno de uma avaliação do estatuto político da ciência ou na determinação das funções ideológicas que a ela se atribuíam. Para Foucault, era imprescindível encontrar meios de ultrapassar os universais históricos da razão e do progresso, próprios do Iluminismo, que caracterizavam a maquinaria filosófica hegeliana e que designavam a maioria dos intelectuais identificados com as correntes marxistas, estas, por sua vez, predominantes em quase toda a atividade crítica social de então.

Numa conferência que proferiu em Tóquio na primavera de 1978 tomou, como exemplo dessa transformação do papel contemporâneo do intelectual, o caso de uma disciplina que conhecia bem: a filosofia. Parecia-lhe que talvez ela pudesse desempenhar um papel de contrapoder. A condição para isso estaria em que esse papel não consistisse mais em impor, em face do poder, a própria lei da filosofia, e que ela deixasse de se pensar, simultaneamente, como profecia, pedagogia ou legislação. Isso porque, Foucault (2011d, p. 154) já o havia dito bem antes, "o papel da filosofia não é forçosamente o de adoçar a existência dos homens e lhes prometer alguma coisa como uma felicidade".

Ao contrário, à filosofia seria reservada a tarefa de "intensificar as lutas que se desenrolam em torno do poder, as estratégias dos adversários no interior das relações de poder, as táticas utilizadas, os focos de resistência" (FOUCAULT, 2004c, p. 43). Numa palavra, que se não continuasse a arbitrar a questão do poder por intermédio de uma sobrecarga de tipo moral e jurídico - via dicotomia bem versus mal, ou legítimo versus ilegítimo -, mas que se a substituísse por uma questão na aparência ingênua e que, a seu ver, não era frequentemente formulada: em que consistem, precisamente, as relações de poder? 
Por esse caminho, a filosofia abraçaria o desígnio de tornar visível não o escondido, mas o próximo e imediato, justamente aquilo que está tão intimamente conectado a nós mesmos e que, por isso mesmo, dele não nos apercebemos. Para Foucault (2004c, p. 44), a questão fulcral era: "quais são as relações de poder às quais estamos presos e nas quais a própria filosofia, pelo menos há 150 anos, está paralisada?"

Novamente, aqui, o pensador francês evoca a possibilidade da fundação de uma espécie de olhar descentrado, preocupado em circunscrever a partir de si mesmo um plano de exterioridade e, uma vez instalado nesse novo ponto de observação, a debruçar-se sobre o que estaria em funcionamento no seu interior: os jogos de linguagem imanentes ao saber filosófico sendo substituídos pela análise das relações que sustentam o pensamento no território social.

Já na introdução de $A$ arqueologia do saber Foucault dava a conhecer que seu percurso intelectual consubstanciava uma recusa radical às territorializações identitárias. Era imperioso que dissesse que não era isto nem aquilo. Foi para inscrever a possibilidade de uma heteronomia congênita - uma ausência de rosto - que apresentou um diálogo em que ele mesmo respondia a um interlocutor imaginário acerca do sentido da existência sob o impacto do exercício da escrita. Com ele, encerrou a apresentação de $A$ arqueologia do saber:

Você pensa que eu teria tanta dificuldade e tanto prazer em escrever, que eu me teria obstinado nisso, cabeça baixa, se não preparasse - com as mãos um pouco febris - o labirinto onde me aventurar, deslocar meu propósito, abrir-lhe subterrâneos, enterrá-lo longe dele mesmo, encontrar-lhe desvios que resumem e deformam seu percurso, onde me perder e aparecer, finalmente, diante dos olhos que eu não terei mais que encontrar? Vários, como eu sem dúvida, escrevem para não ter mais um rosto. Não me pergunte quem sou e não me diga para permanecer o mesmo: é uma moral de estado civil; ela rege nossos papéis. Que ela nos deixe livre quando se trata de escrever (FOUCAULT, 1987a, p. 20).

Toda uma poética da mutação nos é aqui apresentada. A necessidade de cunhar conceitos e aplicar diferentes instrumentos de análise passaria, em Foucault, a estar menos ligada à recepção e assimilação, em bloco, de 
uma determinada herança intelectual do que à possibilidade de produzir uma forma de produzir conhecimento de tipo idiomático. O confronto com as sucessivas realidades em estudo, tomassem elas um caminho mais de tipo histórico, filosófico, literário, político ou outro qualquer, supunha nele a confecção de toda uma utensilagem específica e de uma nomenclatura inteiramente nova, mas que se devia exaurir por completo no interior das narrativas em que haviam sido geradas. Destarte, seus trabalhos pareciam querer dar-se a conhecer não tanto como veículos de uma paisagem definida, mas, na mão inversa, como um modo singular de construir uma dramaturgia espaço-temporal aos olhos dos seus leitores, que seguramente queria tomar de surpresa.

Com efeito, os textos foucaultianos materializam uma importante ocasião: de que o trabalho científico possa forjar, na sua inteireza, os objetos dos quais estaria autorizado apenas a ser porta-voz. Eles constituiriam, ao contrário, um incitamento à imaginação aberta no campo das ciências sociais e humanas, no interior das quais, então como hoje, quase sempre somos constrangidos pela lógica da arregimentação, que conduz à escola de pensamento, à afiliação militante ou à importação de modelos rígidos como condição de partida das investigações. A réplica foucaultiana, nesse sentido, é certeira:

Eu sou, se quiserem, um empirista cego, quer dizer, estou na pior das situações. Não tenho teoria geral e tampouco tenho um instrumento certo. Eu tateio, fabrico, como posso, instrumentos que são destinados a fazer aparecer objetos. Os objetos são um pouquinho determinados pelos instrumentos, bons ou maus, fabricados por mim. Eles são falsos, se meus instrumentos são falsos... Procuro corrigir meus instrumentos através dos objetos que penso descobrir e, neste momento, o instrumento corrigido faz aparecer que o objeto definido por mim não era exatamente aquele. É assim que eu hesito ou titubeio, de livro em livro (FOUCAULT, 2003h, p. 229).

O essencial do seu empreendimento consiste, assim, em sustentar empiricamente a hipótese de que o afã por explicações universalizantes não poderia persistir como a economia geral que anima e sustenta a prática 
de escrita nas ciências humanas e sociais. Daí que, em vez de pleitear um sentido inequívoco para o mundo e seu devir, a escritura apresentava-se a Foucault como devendo protagonizar um jogo peculiar, cujo único objetivo seria, exatamente, o de não fazer cessar o livre jogo da multiplicação dos enunciados. A síntese totalizadora deveria, portanto, ceder lugar à problematização perene, e cada escrito, tomado tão somente como a condição de emergência de um próximo escrito, viesse ele a ser redigido por ele próprio ou, tanto melhor, por terceiros (FOUCAULT, 1971).

As declarações explicativas acerca da natureza do seu trabalho davam conta de um intuito, que parece ficar mais transparente à medida que sua obra se desenrola, de dar corpo a uma pragmática da diferença. Além de seus livros propriamente e, sobretudo, nos cursos proferidos no Collège de France, iam-se sucedendo escritos por meio dos quais ficava patente a rejeição de todas as tentativas de capturá-lo e encapsulá-lo num saber disciplinar clássico, fosse ele historiográfico ou filosófico stricto sensu. Essa invariável negação identitária supunha que a natureza do seu labor apenas podia ser inteligível na ordem do hibridismo, do trânsito permanente entre fronteiras, bem como da experimentação e da ultrapassagem dessas mesmas fronteiras. Era por essa razão, talvez, que dizia imaginar-se entre pontos de espera e de suspensão e que o que produzia eram apenas ofertas de jogo abertas a todos quantos dele quisessem participar. Repetia que não tomava os seus livros "nem como tratados de filosofia nem estudos históricos", mas, no máximo, como "fragmentos filosóficos em canteiros históricos" (FOUCAULT, 2003f, p. 336). Tome-se como exemplo o caso do seu último grande projeto de escrita, o da História da sexualidade, iniciado em 1976 com aparecimento do primeiro volume e concluído somente oito anos depois com a publicação dos segundo e terceiro. As previsões iniciais de Foucault foram-se alterando significativamente no decurso da pesquisa; a introdução ao segundo volume dava conta do resultado a que chegara a sua exigência de reformulação teórica e metodológica, após tantos e variados riscos, interrogações e abandonos. A investigação que então oferecia ao público leitor era, portanto, o resultado de uma experiência que materializou um exercício longo, hesitante e que precisou ser retomado e corrigido. Isso porque o programa de publicação previsto inicialmente 
desorganizara-se ao longo do processo de trabalho. Aos poucos, o exercício foi-se tornando intimamente filosófico, consistindo em procurar "saber em que medida o trabalho de pensar sua própria história pode liberar o pensamento daquilo que ele pensa silenciosamente, e permitir-lhe pensar diferente" (FOUCAULT, 1984, p. 14).

$\mathrm{O}$ ato de conhecer afastava-se, assim, da lógica tradicional do reconhecimento, da legitimação do que se sabe de antemão, da demonstração e da prova, para inaugurar, em seu lugar, uma dinâmica do olhar e da reflexão em direção ao múltiplo, ao distante e ao inusitado. Uma interrogação determinante então tomava vulto: "De que valeria a obstinação do saber se ele assegurasse apenas a aquisição dos conhecimentos e não, de certa maneira, e tanto quanto possível, o descaminho daquele que conhece?" (FOUCAULT, 1984, p. 13). Daí seu acometimento a uma espécie de uma potência móvel do pensamento, alimentada por uma prática de reescrita necessariamente inconclusa.

Assim imaginada e levada a cabo, a prática da escrita era totalmente colocada ao serviço de uma arte geral de existir, consistindo no trabalho sistemático de desprendimento de si mesmo. Tratava-se, portanto, de empreender uma modalidade ética que explicitamente se situava nos antípodas da conversão do outro. É-se para si escrevendo livros, Foucault (2004e, p. 249) parecia estar sempre a repetir, sendo que em cada um deles a análise devia descobrir novas formas de interrogar "os postulados, sacudir os hábitos, as maneiras de fazer e pensar, dissipar as familiaridades aceitas".

Ademais, o pensador francês insistiu na premissa segundo a qual o eu não nos é dado e que, dessa evidência fundamental, poder-se-ia deduzir também a consequência prática mais decisiva: a da autocriação como obra de arte. A ética da existência foucaultiana - sempre apresentada como "a prática refletida da liberdade" (FOUCAULT, 2004b, p. 267) exigia, assim, autocriação onde outros descobriam quase sempre revelação interior e autenticidade, frutos estes de uma saturação psicologizante da cultura. Numa entrevista a Werner Schroeter, em 1982, Foucault (2011a, p. 107-108) é explícito quanto à necessidade de uma atitude de esquiva em relação ao discurso biográfico de raiz psicologizante: 


\begin{abstract}
A arte de viver implica matar a psicologia, criar consigo mesmo e com os outros individualidades, seres, relações, qualidades inominadas. Se não pudermos chegar a fazer isso na vida, ela não merece ser vivida. Não faço diferença entre as pessoas que fazem de sua existência uma obra e aquelas que fazem uma obra em sua existência. Uma existência pode ser uma obra perfeita e sublime, o que os gregos sabiam. Nós o esquecemos completamente, sobretudo depois do Renascimento.
\end{abstract}

Era então que se mostrava surpreendido com o fato de que, no mundo social contemporâneo, a arte se tivesse transformado "em algo relacionado apenas a objetos e não a indivíduos ou à vida" (FOUCAULT, 1995b, p. 261), lastimando que remetesse apenas a uma prática especializada feita por artistas. E, por isso, lançava duas perguntas decisivas: "entretanto, não poderia a vida de todos se transformar numa obra de arte? Por que deveria uma lâmpada ou uma casa ser um objeto de arte, e não a nossa vida?" (FOUCAULT, 1995b, p. 261).

Foucault parecia acreditar que uma multidão de estilos de existência irromperia a partir de uma prática de trabalho de tipo estóico. Em lugar de remeter para a concordância e harmonia de ideias, o cerne da atitude pessoal de um pensador deveria, para ele, ser deduzido em sua "filosofia como vida, em sua vida filosófica, em seu ethos (FOUCAULT, 2004f, p. 219). Assumia, então, que a coerência de seu projeto intelectual era essencialmente de natureza estratégica e apenas conduzida pelo ensejo ético que tomava para si mesmo: "se eu luto por tal questão ou por tal outra, eu o faço porque, de fato, essa luta é importante para mim, em minha subjetividade" (FOUCAULT, 2002, p. 344).

\title{
3 Conclusões
}

Por meio do ofício da escrita, Foucault desejava inserir-se no mundo - que entendia constituir-se perpetuamente numa rede infinita de poderes - lutando com obstinação contra a potência destrutiva que tão bem sabia abater-se sobre si. Entretanto, onde esta estivesse, estaria em germe, igualmente, a possibilidade da diferença e da mudança. Por isso, convocou-nos a imaginar que qualquer análise da dinâmica interior de uma determinada forma de poder que se proponha a colocar em cena o 
que de arbitrário existe no familiar, criará porventura um tipo de nudez que tornará esse mesmo poder susceptível de interpelação e, quiçá, de desmonte. Toda busca da análise foucaultiana é, portanto, eminente e radicalmente crítica, na medida em que visa colocar em crise determinadas formas de veridicção, bem como as matrizes normativas e os modos de existência delas decorrentes, sem, contudo, ambicionar nenhum tipo de salvacionismo.

Atrajetória intelectual de Michel Foucault pode ser tomada como um convite a uma prática da separação não dilacerada, nem triunfalizante, das formas de pensamento e, por extensão, de subjetivação que se desenvolvem em nosso entorno. Seus posicionamentos, por meio dos livros, dos cursos ou da gama de seus ditos e escritos, insistiram, em uníssono, que o gesto de desvio tinha origem num exercício escritural que tornasse possível a proposição de uma dispersão e de uma desorganização ontológica para além das soluções que o presente se encarrega de apresentar a nossos olhos como evidências sem contestação.

\section{Referências}

FOUCAULT, Michel. Conversa com Werner Schroeter. In:

Repensar a política: Ditos \& escritos VII. Rio de Janeiro: Forense Universitária, 2011a. p. 102-112.

- Entrevista com Michel Foucault. In: . Arte, epistemologia, filosofia e história da medicina: Ditos \& escritos VII. Rio de Janeiro: Forense Universitária, 2011b. p. 157-168.

. Foucault responde a Sartre. In: .Arte, epistemologia, filosofia e história da medicina: Ditos \& escritos VII. Rio de Janeiro: Forense Universitária, 2011c. p. 169-175.

. O Homem está morto? In: . Arte, epistemologia, filosofia e história da medicina: Ditos \& escritos VII. Rio de Janeiro: Forense Universitária, 2011d. p. 151-156.

. Conversa com Michel Foucault. In: . Repensar a política: Ditos \& escritos VI. Rio de Janeiro: Forense Universitária, 2010a. p. 289-347. 
. É importante pensar? In: . Repensar a política: Ditos \& escritos VI. Rio de Janeiro: Forense Universitária, 2010b. p. 354358.

. Prefácio (Anti-Édipo). In: - Repensar a política: Ditos \& escritos VI. Rio de Janeiro: Forense Universitária, 2010c. p. 103106.

. O governo de si e dos outros: curso no Collège de France (1982-1983). São Paulo: Martins Fontes, 2010d.

. O intelectual e os poderes. In: . Repensar a política: Ditos \& escritos VI. Rio de Janeiro: Forense Universitária, 2010e. p. 371 376.

. O poder, uma besta magnífica. In: . Repensar a política: Ditos \& escritos VI. Rio de Janeiro: Forense Universitária, $2010 \mathrm{f}$. p. 155-169.

. Para uma moral do desconforto. In: Repensar a política: Ditos \& escritos VI. Rio de Janeiro: Forense Universitária, $2010 \mathrm{~g}$. p. 279-284.

. Eu sou um pirotécnico. In: POL-DROIT, Roger. Michel Foucault, entrevistas. São Paulo: Graal, 2006. p. 67-100.

. A escrita de si. In:

Ética, sexualidade, politica:

Ditos \& escritos V. Rio de Janeiro: Forense Universitária, 2004a. p. 144162.

A ética do cuidado de si como prática da liberdade. In: . Ética, sexualidade, política: Ditos \& escritos V. Rio de Janeiro: Forense Universitária, 2004a. p. 264-287.

- A filosofia analítica da política. In: - Ética, sexualidade, política: Ditos \& escritos V. Rio de Janeiro: Forense Universitária, 2004c. p. 37-55. $\overline{2004 d, \text { p. } 10 .}$

. A palavra nua. Folha de São Paulo, Mais!, São Paulo, 21 nov.

. O cuidado com a verdade. In: Ética, sexualidade, política: Ditos \& escritos V. Rio de Janeiro: Forense Universitária, 2004e. p. 240-251. 
. O retorno da moral. In: . Ética, sexualidade, politica. Ditos \& escritos V. Rio de Janeiro: Forense Universitária, 2004f. p. 252-263.

. Política e ética: uma entrevista. In: . Ética, sexualidade, politica: Ditos \& escritos V. Rio de Janeiro: Forense Universitária, 2004g. p. 218-224.

. Verdade, poder e si mesmo. In: Ética, sexualidade, politica: Ditos \& escritos V. Rio de Janeiro: Forense Universitária, 2004h. p. 294-300.

A vida dos homens infames. In: . Estratégia, podersaber: Ditos \& escritos IV. Rio de Janeiro: Forense Universitária, 2003a. p. 203-222.

. Conversação com Michel Foucault. In: Estratégia, poder-saber: Ditos \& escritos IV. Rio de Janeiro: Forense Universitária, 2003b. p. 13-25.

. Entrevista sobre a prisão: o livro e seu método. In:

Estratégia, poder-saber: Ditos \& escritos IV. Rio de Janeiro: Forense Universitária, 2003c. p. 159-174.

. Foucault estuda a razão de Estado. In: Estratégia, poder-saber: Ditos \& escritos IV. Rio de Janeiro: Forense Universitária, 2003d. p. 317-322.

. M. Foucault. Conversação sem complexos com um filósofo que analisa as "estruturas do poder". In: . Estratégia, podersaber: Ditos \& escritos IV. Rio de Janeiro: Forense Universitária, 2003e. p. 306-316.

- Mesa-redonda em 20 de maio de 1978. In:

Estratégia, poder-saber: Ditos \& escritos IV. Rio de Janeiro: Forense Universitária, 2003f. p. 335-351.

. Os intelectuais e o poder. M. Foucault. Conversação sem complexos com um filósofo que analisa as "estruturas do poder". In: . Estratégia, poder-saber: Ditos \& escritos IV. Rio de Janeiro: Forense Universitária, 2003g. p. 37-47. 
. Poder e saber. In: . Estratégia, poder-saber: Ditos \& escritos IV. Rio de Janeiro: Forense Universitária, 2003h. p. 223-240.

- Entrevista com Michel Foucault. In:

Problematização do sujeito: psicologia, psiquiatria e psicanálise. Ditos \& escritos I. 2. ed. Rio de Janeiro: Forense Universitária, 2002. p. 331-344.

. Linguagem e literatura. In: MACHADO, Roberto. Foucault, a filosofia e a literatura. 2. ed. Rio de Janeiro: Jorge Zahar, 2001a. p. 137174.

. O que é um autor? In: . Estética: literatura e pintura, música e cinema. Ditos \& escritos III. Rio de Janeiro: Forense Universitária, 2001b. p. 264-298.

. O filósofo mascarado. In: . Arqueologia das ciências e história dos sistemas de pensamento: Ditos \& escritos II. Rio de Janeiro: Forense Universitária, 2000a. p. 299-306.

. Prefácio à edição inglesa. In: . Arqueologia das ciências e história dos sistemas de pensamento: Ditos \& escritos II. Rio de Janeiro: Forense Universitária, 2000b. p. 182-188.

. Sobre a arqueologia das ciências. Resposta ao Círculo de Epistemologia. In: . Arqueologia das ciências e história dos sistemas de pensamento: Ditos \& escritos II. Rio de Janeiro: Forense Universitária, 2000c. p. 82-118.

. Raymond Roussel. Rio de Janeiro: Forense Universitária, 1999.

. O sujeito e o poder. In: DREYFUS, H.; RABINOW, P. Michel Foucault, uma trajetória filosófica. Rio de Janeiro: Forense Universitária, 1995a. p. 231-249.

. Sobre a genealogia da ética: uma revisão do trabalho. In: DREYFUS, Hubert; RABINOW, Paul. Michel Foucault, uma trajetória filosófica. Rio de Janeiro: Forense Universitária, 1995b. p. 253-278.

. A arqueologia do saber. 3. ed. Rio de Janeiro: Vozes, 1987a.

. Vigiar e punir: o nascimento da prisão. Petrópolis: Vozes,

1987b. 
. História da sexualidade 2: o uso dos prazeres. Rio de Janeiro: Graal, 1984.

. Entrevista com Michel Foucault (entrevista com J. G. Merquior e S. P. Rouanet). In:___ (et. al.). O homem e o discurso (a arqueologia de Michel Foucault). Rio de Janeiro: Tempo Brasileiro, 1971. p. 17-42.

Data de registro: $29 / 04 / 2012$

Data de aceite: $22 / 01 / 2014$ 